\title{
Development and Validation of Absorption Correction UV- Spectrophotometry Method for Simultaneous Estimation of Ranitidine HCL and Dicyclomine Hydrochloride in Their Marketed Formulation
}

\author{
Bhumi Kantariya*, Dr Greeva Bhatt, Dr. Mehul Mehta, Urmi Kanatria, Ravi Dalsaniya \\ Lecturer Department of Pharmaceutical Chemistry, Indian Institute of Ayurvedic Pharmaceutical Sciences, \\ Gujarat Ayurved University, Jamnagar, Gujarat, India
}

\begin{abstract}
A Simple, selective, precise and rapid absorption correction Spectrophotometric method has been developed and validated as per ICH guideline for the simultaneous estimation of Ranitidine Hydrochloride and Dicyclomine Hydrochloride in tablet dosage form. Method is base on UV Spectrophotometric for determination of two drug, by using Methanol as a solvent and diluted the same with $0.1 \mathrm{~N} \mathrm{NaOH}$, solution. In this UV method, the two wavelength were selected, $311.4 \mathrm{~nm}$ and at $217 \mathrm{~nm}$ for RANTD and DICY, respectively. this method was validated according to ICH guideline and Linearity range, was found to be $7.5-37.5 \mu \mathrm{g} / \mathrm{ml}$ and $1-5$ $\mu \mathrm{g} / \mathrm{ml}$ for RANTD and DICY, respectively. The method was successfully applied to assay drugs in tablet.
\end{abstract}

Keywords :- UV Spectrophotometric absorption correction method; Ranitidine Hydrochloride (RANTD); Dicyclomine Hydrochloride (DICY); ICH guidelines; Validation.

\section{INTRODUCTION}

Ranitidine Hydrochloride

$\mathrm{N}-(2-[(5-$

(dimethylaminomethyl) furan-2-yl) methylthio]ethyl)- N-methyl- 2- nitroethene- 1,1diamine (Figure 1) is histamine H2 receptor antagonist. Dicyclomine Hydrochloride 2(diethylamino) ethyl cyclohexylcyclohexane-1carboxylate (Figure 2) is antiemetic, antimuscarinics and anticholinergic agent. Combination is frequently used in the treatment of acute ulcer.[32-37] A literature survey revealed there are many analytical methods reported for estimation of Ranitidine Hydrochloride \& Dicyclomine Hydrochloride in individuals \& in combination with other drugs in bulk and pharmaceutical dosage forms.[45-52] We have developed and validate new specific, very simple, accurate, precise spectrophotometry for estimation of marketed drug formulations.<smiles>CN/C(=C\[N+](=O)[O-])NCCSCc1ccc(CN(C)C)o1</smiles>

Figure 1 : Ranitidine Hydrochloride

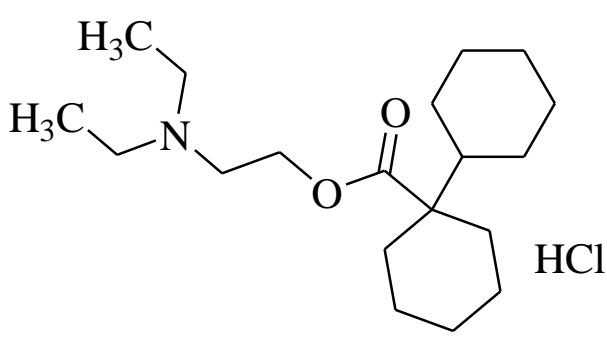


Bhumi Kantariya et al Int J Sci Res Sci Technol. March-April-2019; 6 (2) : 851-863

Figure 2 : Dicyclomine Hydrochloride 


\section{MATERIALS AND METHODS}

\subsection{MATERIALS}

Standard bulk drug samples of Ranitidine hydrochloride and Dicyclomine hydrochloride were provided by Yarrow chem. Mumbai Tablets of combined dosage form were procured from the local market. AR grade Methanol and $\mathrm{NaOH}$ were obtained from Molychem Limited, Mumbai.

\subsection{INSTRUMENTATION}

Spectrophotometric analysis was developed on a computer controlled Shimadzu UV-Visible spectrophotometer 1800, double beam spectrophotometer with spectral width $1 \mathrm{~nm}$ using 10 $\mathrm{mm}$ quartz cells. Absorption correction method UV spectra for the solution of RANTD and DICY were recorded in a $10 \mathrm{~mm}$ cell over the range $200-400 \mathrm{~nm}$ using methanol in the reference cell.

\subsection{PREPARATION OF SOLUTIONS}

2.3.1 Preparation of standard stock solution of Ranitidine Hydrochloride (RANTD)

Accurately weighed quantity of Ranitidine Hydrochloride $150 \mathrm{mg}$ (equivalent to Ranitidine) was transferred into $100 \mathrm{ml}$ volumetric flask. Add $60 \mathrm{ml}$ methanol; sonicated for $10 \mathrm{~min}$ and final volume was made $100 \mathrm{ml}$ with the same to get stock solution containing $1500 \mu \mathrm{g} / \mathrm{ml}$ of RANTD.

\subsubsection{Preparation of working stock solution of RANTD}

A solution of $150 \mu \mathrm{g} / \mathrm{ml}$ of RANTD was prepared by diluting $10 \mathrm{ml}$ of standard stock solution with methanol in $100 \mathrm{ml}$ volumetric flask up to the mark.

2.3.3 Preparation of standard stock solution of Dicyclomine Hydrochloride (DICY)

Accurately weighed quantity of Dicyclomine Hydrochloride $100 \mathrm{mg}$ was transferred into $100 \mathrm{ml}$ volumetric flask. Add $60 \mathrm{ml}$ methanol; sonicated for $10 \mathrm{~min}$ and final volume was made $100 \mathrm{ml}$ with the same to get stock solution containing $1000 \mu \mathrm{g} / \mathrm{ml}$ of DICY.

\subsubsection{Preparation of working stock solution of DICY}

A solution of $20 \mu \mathrm{g} / \mathrm{ml}$ of DICY was prepared by diluting $2 \mathrm{ml}$ of standard stock solution with methanol in $100 \mathrm{ml}$ volumetric flask up to the mark.

\subsubsection{Preparation of working stock solution of Mixture of RANTD and DICY}

Pipette out $10 \mathrm{ml}$ of standard stock solution of RANTD and $2 \mathrm{ml}$ of standard stock of DICY in to a $100 \mathrm{ml}$ volumetric flask. Dilute it to $100 \mathrm{ml}$ with methanol to get $150 \mu \mathrm{g} / \mathrm{ml}$ of Ranitidine Hydrochloride and $20 \mu \mathrm{g} / \mathrm{ml}$ of Dicyclomine Hydrochloride.

\subsubsection{Preparation of sample stock solution of Mixture of RANTD and DICY}

Twenty tablets weight; average weight determined and crush to fine powder in a glass motar. Powder equivalent to the $15 \mathrm{mg}$ of RANTD and $2 \mathrm{mg}$ of DICY was weighed and transferred in to the $100 \mathrm{ml}$ of volumetric flask, dissolved in $60 \mathrm{ml}$ methanol and sonicate it for 15 minutes. Filter the solution through Whatman filter paper no.42 and diluted up to mark with same.

It gives the solution of RANTD $150 \mu \mathrm{g} / \mathrm{ml}$. and DICY $20 \mu \mathrm{g} / \mathrm{ml}$.

\subsection{Validation of Proposed Method [23-31]}

\subsubsection{Linearity and Range}

The linearity was evaluated through a linear regression analysis. The linearity for RANTD (7.5$37.5 \mu \mathrm{g} / \mathrm{ml})$ and DICY $(1-5 \mu \mathrm{g} / \mathrm{ml})$ was determined in terms of correlation coefficient.

Preparation of the solution for calibration curve of RANTD

The series consisted of solutions having different concentrations of standard RANTD solution ranging from $7.5-37.5 \mu \mathrm{g} / \mathrm{ml}$. The solutions were prepared by pipetting out $0.51 .0,1.5,2.0$ and $2.5 \mathrm{ml}$ of the 
working stock solution of RANTD $(150 \mu \mathrm{g} / \mathrm{ml})$ into series of $10 \mathrm{ml}$ volumetric flasks and the volume was adjusted to mark with $0.1 \mathrm{~N} \mathrm{NaOH}$ solution.

\section{Preparation of the solution for calibration curve of DICY}

The series consisted of solutions having different concentrations of standard DICY solution ranging from $1-5 \mu \mathrm{g} / \mathrm{ml}$. The solutions were prepared by pipetting out $0.51 .0,1.5,2.0$ and $2.5 \mathrm{ml}$ of the working stock solution of DICY $(20 \mu \mathrm{g} / \mathrm{ml})$ into series of $10 \mathrm{ml}$ volumetric flasks and the volume was adjusted to mark with $0.1 \mathrm{~N} \mathrm{NaOH}$ solution.

\subsubsection{Precision}

Precision was considered at different levels, i.e. Method Precision, System Precision, Intraday and Interday.

\section{Repeatability}

Repeatability was studied by carrying out System precision and Method Precision.

System Precision was determined from results for six replicate of mixture of drug substances.

Take $1.0 \mathrm{ml}$ of working stock solution of mixture of RANTD and DICY $(150 \mu \mathrm{g} / \mathrm{ml}$ and $20 \mu \mathrm{g} / \mathrm{ml}$ respectively), transferred into $10 \mathrm{ml}$ volumetric flask and diluted up to mark with $0.1 \mathrm{~N} \mathrm{NaOH}$ solution to get solution containing $15 \mu \mathrm{g} / \mathrm{ml}$ RANTD and $2 \mu \mathrm{g} / \mathrm{ml}$ DICY.

Mixed solutions containing $15 \mu \mathrm{g} / \mathrm{ml}$ RANTD and $2 \mu \mathrm{g} / \mathrm{ml}$ DICY were analyzed 6 times and \%RSD was calculated. (Table 3)

Method Precision was determined from results for six replicates of formulation.

Take $1.0 \mathrm{ml}$ of sample stock solution RANTD and DICY $(150 \mu \mathrm{g} / \mathrm{ml}$ and $20 \mu \mathrm{g} / \mathrm{ml}$ respectively), transferred into $10 \mathrm{ml}$ volumetric flask and diluted up to mark with $0.1 \mathrm{~N} \mathrm{NaOH}$ solution to get solution containing $15 \mu \mathrm{g} / \mathrm{ml}$ RANTD and $2 \mu \mathrm{g} / \mathrm{ml}$ DICY.
These solutions containing $15 \mu \mathrm{g} / \mathrm{ml}$ RANTD and 2 $\mu \mathrm{g} / \mathrm{ml}$ DICY were analyzed 6 times and \%RSD was calculated. (Table 4)

\section{Intraday \& Interday}

Intraday precision was determined by analyzing the combined solution containing the concentration 15 , 22.5 and $30 \mu \mathrm{g} / \mathrm{ml}$ of RANTD and 2, 3 and 4 of DICY, for 3 times in the same day. Interday precision was determined by the same concentration of drug daily for 3 days. \% RSD was calculated for both intraday and interday. (prepared by pipetting out 1.0, 1.5, 2.0 $\mathrm{ml}$ of working stock solution of mixture into $10 \mathrm{ml}$ volumetric flasks and diluted up to mark with $0.1 \mathrm{~N}$ $\mathrm{NaOH})$ in triplicates analyzed three times on the same day and \% RSD was calculated. (Table 5 \& 6)

\subsubsection{LOD (Limit of Detection) and LOQ (Limit of Quantification)}

The LOD is estimated from the set of 5 calibration curves used to determine method linearity.

The LOD may be calculated as

\section{$L O D=3.3 x(S D /$ Slope $)$}

Where, $\mathrm{SD}=$ the standard deviation of $\mathrm{Y}$ - intercept of 5 calibration curves

Slope $=$ the mean slope of the 5 calibration curves.

The LOQ is estimated from the set of 5 calibration curves used to determine method linearity.

The LOQ may be calculated as

\section{$L O Q=10 x(S D /$ Slope $)$}

Where, $\mathrm{SD}=$ the standard deviation of $\mathrm{Y}$ - intercept of 5 calibration curves

Slope $=$ the mean slope of the 5 calibration curves. The values of LOD and LOQ are given in Table 7

\subsubsection{Accuracy}

The accuracy of the method was expressed by in term of the recovery study $(80,100$, and $120 \%)$ was carried out by adding known amount of pure drug corresponding to 80,100 , and $120 \%$ to pre analysed sample solution (15 $\mu \mathrm{g} / \mathrm{ml}$ of PCM \& $2 \mu \mathrm{g} / \mathrm{ml}$ of DICY) 
and the samples were reanalysed at each level 3 determination were performed. (Table 8 \&9).The acceptance criteria for percent recovery are between 98 to $102 \%$.

\subsubsection{Assay (Quantification of RANTD and DICY in tablet dosage form)}

Twenty tablets weight; average weight determined and crush to fine powder in a glass motar. Powder equivalent to the $15 \mathrm{mg}$ of RANTD and $2 \mathrm{mg}$ of DICY was weighed and transferred in to the $100 \mathrm{ml}$ of volumetric flask, dissolved in $60 \mathrm{ml}$ methanol and sonicate it for 15 minutes. Filter the solution through Whatman filters paper no.42 and diluted up to mark with same.It gives the solution of RANTD $150 \mu \mathrm{g} / \mathrm{ml}$. and DICY $20 \mu \mathrm{g} / \mathrm{ml}$.The filtrate of $5.0 \mathrm{ml}$ transfered in to $50 \mathrm{ml}$ volumetric flask and volume was adjusted up to the mark with methanol to obtain the concentration of $15 \mu \mathrm{g} / \mathrm{ml}$ of RANTD and $2 \mu \mathrm{g} / \mathrm{ml}$ of DICY. (Table 11)

\section{RESULT AND DISCUSSION}

From the stock solutions, working standard solutions of RANTD $(100 \mu \mathrm{g} / \mathrm{ml})$ and DICY $(20 \mu \mathrm{g} / \mathrm{ml})$ were prepared. By appropriate dilutions, the solutions with concentrations 7.5-37.5 $\mu \mathrm{g} / \mathrm{ml}$ (for RANTD) and 1$5 \mu \mathrm{g} / \mathrm{ml}$ (for DICY) were prepared and scanned between 200 to $400 \mathrm{~nm}$.

For RANTD and DICY, analytical wavelengths of $311.4 \mathrm{~nm}$ and $217 \mathrm{~nm}$ were selected respectively. Absorptivity of RANTD and DICY were calculated at both the wavelengths.

The concentrations of RANTD and DICY can be calculated from following equations:

\footnotetext{
$\mathrm{C}_{\mathrm{x}}(\mathrm{RANTD})=\mathrm{A}_{2} / \mathrm{a} \mathrm{x} 2$

$\mathrm{C}_{\mathrm{y}}(\mathrm{DICY})=\mathrm{A}_{1}-\mathrm{a}_{\mathrm{x} 1} \mathrm{C}_{\mathrm{x}}$ (RANTD) $/ \mathrm{a}_{\mathrm{y} 1}$
}

Where, $A_{1}=$ absorbance of mixture at $217 \mathrm{~nm}$

$\mathrm{A}_{2}=$ absorbance of mixture at $311.4 \mathrm{~nm}$ $\mathrm{a}_{\mathrm{x} 1}=$ absorptivity of RANTD at $217 \mathrm{~nm}$ $\mathrm{ax} 2=$ absorptivity of RANTD at $311.2 \mathrm{~nm}$

ay1= absorptivity of DICY at $217 \mathrm{~nm}$

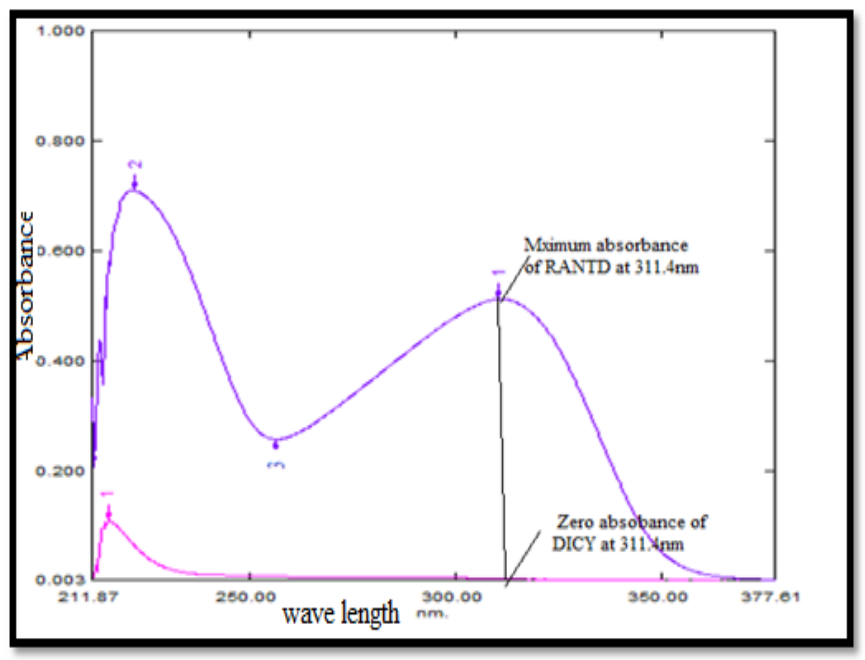

Figure 3 : Zero order overlain spectra of Ranitidine Hydrochlorideand Dicyclomine Hydrochloride

\subsection{Linearity and Range}

The linearity range for Ranitidine Hydrochloride and Dicyclomine Hydrochloride were found to be in the range of $7.5-37.5 \mu \mathrm{g} / \mathrm{ml} \& 1-5 \mu \mathrm{g} / \mathrm{ml}$, respectively. (Table 6.4.1 \& 6.4.2)

Correlation co-efficient for calibration curve of RANTD and DICY were found to be 0.999 and 0.999 , respectively.

The regression line equation for RANTD and DICY are as following, (Figure 2\&3)

YRANTD $=0.034 \mathrm{x}+0.0001$

$\mathrm{Y}$ DICY $=0.090 \mathrm{x}+0.020$

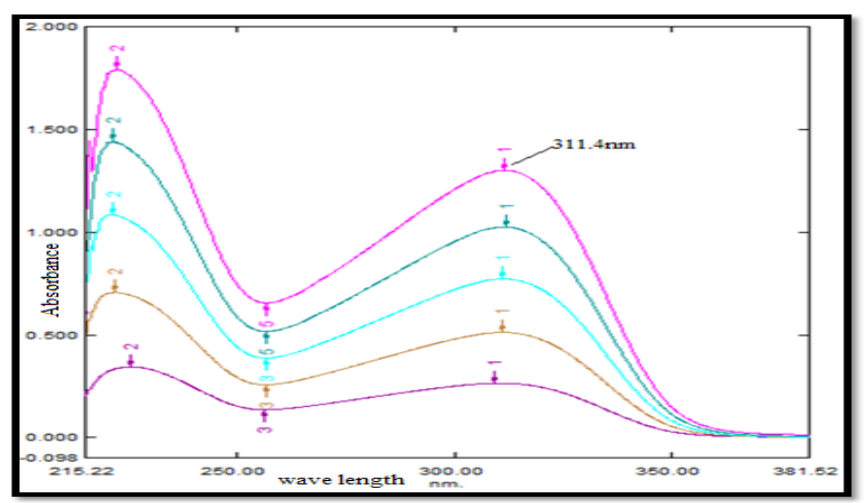

Figure 4: Linearity spectra of RANTD 


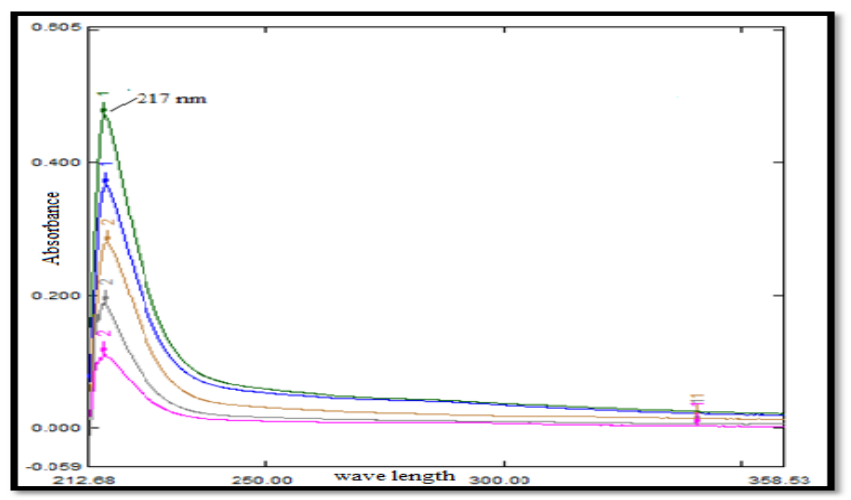

Figure 5: Linearity spectra of DICY

Table 1: Result of linearity study for standard RANTD at $311.4 \mathrm{~nm}$

\begin{tabular}{|c|l|l|r|}
\hline $\begin{array}{l}\text { Sr.N } \\
\text { o. }\end{array}$ & $\begin{array}{l}\text { Concentration } \\
(\mu \mathrm{g} / \mathrm{ml})\end{array}$ & $\begin{array}{l}\text { Absorbance } \\
\text { Mean } \pm \text { S.D. (n=5) }\end{array}$ & $\begin{array}{l}\text { \%R } \\
\text { SD }\end{array}$ \\
\hline 1 & 7.5 & $0.265 \pm 0.0006$ & 0.22 \\
\hline 2 & 15 & $0.512 \pm 0.0005$ & 0.09 \\
\hline 3 & 22.5 & $0.773 \pm 0.0005$ & 0.07 \\
\hline 4 & 30 & $1.025 \pm 0.0008$ & 0.08 \\
\hline 5 & 37.5 & $1.300 \pm 0.0010$ & 0.08 \\
\hline
\end{tabular}

Table 2: Result of linearity study for standard DICY at $217 \mathrm{~nm}$

\begin{tabular}{|c|l|l|c||}
\hline Sr.No. & $\begin{array}{l}\text { Concentration } \\
(\mu \mathrm{g} / \mathrm{ml})\end{array}$ & $\begin{array}{l}\text { Absorbance } \\
\text { Mean } \pm \text { S.D. } \\
(\mathbf{n}=5)\end{array}$ & \%RSD \\
\hline 1 & 1 & $0.118 \pm 0.002$ & 1.40 \\
\hline 2 & 2 & $0.198 \pm 0.005$ & 0.29 \\
\hline 3 & 3 & $0.283 \pm 0.001$ & 0.53 \\
\hline 4 & 4 & $0.376 \pm 0.004$ & 1.11 \\
\hline 5 & 5 & $0.480 \pm 0.006$ & 0.95 \\
\hline
\end{tabular}




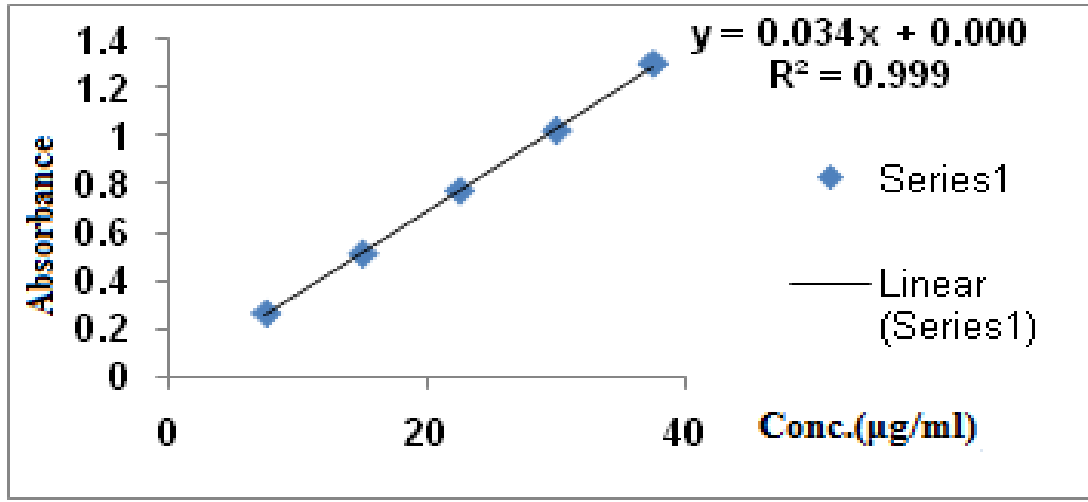

Figure 6 : Calibration curve of RANTD at $311.4 \mathrm{~nm}$.

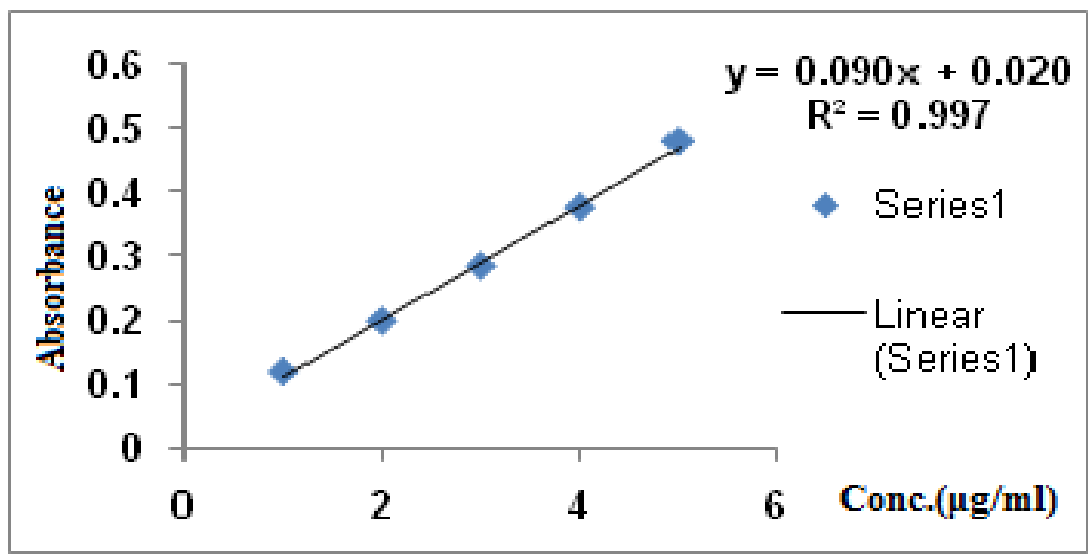

Figure 7 : Calibration curve of DICY at $217 \mathrm{~nm}$.

\subsection{Precision}

\section{Repeatability}

Result of repeatability in terms of System precision and Method Precision.

Table 3: Results of System precision for RANTD and DICY at $311.4 \mathrm{~nm}$ and $217 \mathrm{~nm}$, respectively

\begin{tabular}{|c|c|c|c|c|c|c|c|}
\hline \multirow[b]{2}{*}{$\begin{array}{l}\text { Conc. } \\
(\mu \mathrm{g} / \mathrm{ml})\end{array}$} & \multicolumn{3}{|l|}{ RANTD } & \multirow[b]{2}{*}{$\begin{array}{l}\text { Conc. } \\
(\mu \mathrm{g} / \mathrm{ml})\end{array}$} & \multicolumn{3}{|l|}{ DICY } \\
\hline & Absorbance & $\begin{array}{l}\text { Mean* } \\
\pm \text { S.D. }\end{array}$ & \%RSD & & Absorbance & $\begin{array}{l}\text { Mean* } \\
\pm \text { S.D. }\end{array}$ & \%RSD \\
\hline 15 & 0.545 & \multirow{6}{*}{$0.543 \pm 0.0013$} & \multirow{6}{*}{0.24} & 2 & 1.101 & \multirow{6}{*}{$1.099 \pm 0.0024$} & \multirow{6}{*}{0.22} \\
\hline 15 & 0.544 & & & 2 & 1.102 & & \\
\hline 15 & 0.544 & & & 2 & 1.099 & & \\
\hline 15 & 0.543 & & & 2 & 1.100 & & \\
\hline 15 & 0.544 & & & 2 & 1.098 & & \\
\hline 15 & 0.541 & & & 2 & 1.095 & & \\
\hline
\end{tabular}


* Average of six determinations.

\% RSD for System precision for combined solution of RANTD and DICY were found to be $0.24 \%$ for RANTD and $0.22 \%$ for DICY.

Table 4: Results of Method precision for RANTD and DICY at $311.4 \mathrm{~nm}$ and $217 \mathrm{~nm}$, respectively

\begin{tabular}{|c|c|c|c|c|c|c|c|}
\hline \multirow[b]{2}{*}{$\begin{array}{l}\text { Conc. } \\
(\mu \mathrm{g} / \mathrm{ml})\end{array}$} & \multicolumn{3}{|l|}{ RANTD } & \multirow[b]{2}{*}{$\begin{array}{l}\text { Conc. } \\
(\mu \mathrm{g} / \mathrm{ml})\end{array}$} & \multicolumn{3}{|l|}{ DICY } \\
\hline & Absorbance & $\begin{array}{l}\text { Mean* } \\
\pm \text { S.D. }\end{array}$ & $\%$ RSD & & Absorbance & $\begin{array}{l}\text { Mean* } \\
\pm \text { S.D. }\end{array}$ & $\% R S D$ \\
\hline 15 & 0.493 & \multirow{6}{*}{$\begin{array}{l}0.493 \pm \\
0.0020\end{array}$} & \multirow{6}{*}{0.41} & 2 & 1.023 & \multirow{6}{*}{$\begin{array}{l}1.021 \pm \\
0.0026\end{array}$} & \multirow{6}{*}{0.260} \\
\hline 15 & 0.491 & & & 2 & 1.021 & & \\
\hline 15 & 0.495 & & & 2 & 1.018 & & \\
\hline 15 & 0.493 & & & 2 & 1.023 & & \\
\hline 15 & 0.491 & & & 2 & 1.019 & & \\
\hline 15 & 0.496 & & & 2 & 1.025 & & \\
\hline
\end{tabular}

* Average of six determinations.

$\%$ RSD for System precision for combined solution of RANTD and DICY were found to be $0.41 \%$ for RANTD and $0.26 \%$ for DICY.

Percentage RSD of repeatability were $<2 \%$ for both drugs, indicates that the method is precise.

\section{Intraday Precision}

Table 5: Results of Intraday precision for RANTD and DICY at $311.4 \mathrm{~nm}$ and $217 \mathrm{~nm}$, respectively

\begin{tabular}{|c|c|c|c|c|c|}
\hline \multicolumn{3}{|l|}{ RANTD } & \multicolumn{3}{|l|}{ DICY } \\
\hline \multirow{2}{*}{$\begin{array}{l}\text { Conc. } \\
(\mu \mathrm{g} / \mathrm{ml})\end{array}$} & Absorbance & \multirow{2}{*}{$\%$ RSD } & \multirow{2}{*}{$\begin{array}{l}\text { Conc. } \\
(\mu \mathrm{g} / \mathrm{ml})\end{array}$} & Absorbance & \multirow{2}{*}{$\% R S D$} \\
\hline & Mean $^{*} \pm$ S.D. & & & Mean $^{*} \pm$ S.D. & \\
\hline 15 & $0.544 \pm 0.0005$ & 0.09 & 2 & $1.097 \pm 0.0035$ & 0.31 \\
\hline 22.5 & $0.816 \pm 0.0006$ & 0.06 & 3 & $1.448 \pm 0.0036$ & 0.24 \\
\hline 30 & $1.102 \pm 0.0005$ & 0.04 & 4 & $1.868 \pm 0.0075$ & 0.40 \\
\hline
\end{tabular}


*Average of three determinations

The average \%RSD for intraday precision was found to be $0.06 \%$ and $0.32 \%$ for RANTD and DICY, respectively.

\section{Interday Precision}

Table 6: Results of Interday precision for RANTD and DICY at $311.4 \mathrm{~nm}$ and $217 \mathrm{~nm}$, respectively

\begin{tabular}{|c|c|c|c|c|c|}
\hline \multicolumn{3}{|l|}{ RANTD } & \multicolumn{3}{|l|}{ DICY } \\
\hline \multirow{2}{*}{$\begin{array}{l}\text { Conc. } \\
(\mu \mathrm{g} / \mathrm{ml})\end{array}$} & Absorbance & \multirow{2}{*}{$\%$ RSD } & \multirow{2}{*}{$\begin{array}{l}\text { Conc. } \\
(\mu \mathrm{g} / \mathrm{ml})\end{array}$} & \multirow{2}{*}{$\begin{array}{l}\text { Absorbance } \\
\text { Mean* }^{*} \text { S.D. }\end{array}$} & \multirow{2}{*}{ \%RSD } \\
\hline & Mean $^{*} \pm$ S.D. & & & & \\
\hline 15 & $0.486 \pm 0.0051$ & 1.04 & 2 & $1.089 \pm 0.0037$ & 0.34 \\
\hline 22.5 & $0.778 \pm 0.0015$ & 0.19 & 3 & $1.392 \pm 0.0098$ & 0.70 \\
\hline 30 & $1.085 \pm 0.0049$ & 0.46 & 4 & $1.781 \pm 0.0057$ & 0.31 \\
\hline
\end{tabular}

${ }^{*}$ Average of three determinations

The average \% RSD for interday precision was found to be $0.56 \%$ and $0.44 \%$ for RANTD and DICY, respectively.

Percentage RSD of intraday and interday precision were $<2 \%$ for both drugs, indicates that the method was precise.

\subsection{LOD and LOQ}

Calibration curve was repeated for 5 times and the standard deviation (SD) of the intercepts was calculated. Then LOD and LOQ were measured as follows.

$\mathrm{LOD}=3.3 * \mathrm{SD} /$ slope of calibration curve

$\mathrm{LOQ}=10$ * SD/slope of calibration curve

$\mathrm{SD}=$ Standard deviation of intercepts 
Table 7: Results of LOD and LOQ for RANTD and DICY

\begin{tabular}{||l|l|l||}
\hline \hline Parameter & RANTD $(\mu \mathrm{g} / \mathrm{ml})$ & DICY $(\mu \mathrm{g} / \mathrm{ml})$ \\
\hline SD of intercept & 0.0001 & 0.0056 \\
\hline Slope & 00.034 & 00.09 \\
\hline LOD $(\mu \mathrm{g} / \mathrm{ml})$ & 0.0097 & 0.205 \\
\hline LOQ $(\mu \mathrm{g} / \mathrm{ml})$ & 00.029 & 0.622 \\
\hline
\end{tabular}

\subsection{Accuracy}

Table 8: Results of Recovery study for RANTD

\begin{tabular}{|c|c|c|c|c|c|c|}
\hline $\begin{array}{l}\text { Accuracy } \\
\text { level }\end{array}$ & $\begin{array}{l}\text { Amount of } \\
\text { RANTD in } \\
\text { Sample } \\
(\mu \mathrm{g} / \mathrm{ml})\end{array}$ & $\begin{array}{l}\text { Amount } \\
\text { of } \\
\text { Std } \\
\text { RANTD } \\
\text { added } \\
(\mu \mathrm{g} / \mathrm{ml})\end{array}$ & $\begin{array}{l}\text { Total } \\
\text { amount } \\
\text { of RANTD } \\
(\mu \mathrm{g} / \mathrm{ml})\end{array}$ & $\begin{array}{l}\text { Total amount } \\
\text { of } \quad \text { RANTD } \\
\text { found }(\mu \mathrm{g} / \mathrm{ml}) \\
\text { Mean }(n=3)\end{array}$ & $\begin{array}{l}\% \\
\text { Recovery } \\
(n=3)\end{array}$ & \%RSD \\
\hline $\begin{array}{l}\text { Pre } \\
\text { analyzed }\end{array}$ & 15 & 0 & 15 & 15.14 & - & \\
\hline $80 \%$ & 15 & 12 & 27 & 27.17 & 100.25 & 0.125 \\
\hline $100 \%$ & 15 & 15 & 30 & 29.97 & 98.86 & 0.113 \\
\hline $120 \%$ & 15 & 18 & 33 & 32.97 & 99.05 & 0.103 \\
\hline
\end{tabular}

Table 9: Results of Recovery study for DICY

\begin{tabular}{||l|l|l|l|l|l|l||}
\hline \hline $\begin{array}{l}\text { Accuracy } \\
\text { level }\end{array}$ & $\begin{array}{l}\text { Amount of } \\
\text { DICY in } \\
\text { Sample } \\
(\mu \mathrm{g} / \mathrm{ml})\end{array}$ & $\begin{array}{l}\text { Amount } \\
\text { of } \\
\text { Std DICY } \\
\text { added } \\
(\mu \mathrm{g} / \mathrm{ml})\end{array}$ & $\begin{array}{l}\text { Total } \\
\text { amount } \\
\text { of DICY } \\
(\mu \mathrm{g} / \mathrm{ml})\end{array}$ & $\begin{array}{l}\text { Total amount } \\
\text { of DICY found } \\
(\mu \mathrm{g} / \mathrm{ml}) \\
\text { Mean }(\mathrm{n}=3)\end{array}$ & $\begin{array}{l}\% \\
\text { Recovery } \\
(\mathrm{n}=3)\end{array}$ & \%RSD \\
\hline $\begin{array}{l}\text { Pre } \\
\text { analyzed }\end{array}$ & 2 & 0 & 2 & 2.06 & - & \\
\hline $80 \%$ & 2 & 1.6 & 3.6 & 3.64 & 98.75 & 0.342 \\
\hline $100 \%$ & 2 & 2 & 4 & 4.07 & 100.50 & 0.375 \\
\hline $120 \%$ & 2 & 2.4 & 4.4 & 4.48 & 100.83 & 0.461 \\
\hline
\end{tabular}


Percentage recovery for RANTD was 98.86-100.25\%, while for DICY was 98.75-100.83\%.

Recovery was in the range of $98-102 \%$, indicates that method is accurate.

Table 10: Summary of all parameters

\begin{tabular}{|c|c|c|c|}
\hline \multirow{2}{*}{\multicolumn{2}{|c|}{ Parameters }} & \multicolumn{2}{|l|}{ UV Spectrophotometry } \\
\hline & & \multirow{2}{*}{$\begin{array}{l}\text { RANTD } \\
7.5-37.5\end{array}$} & \multirow{2}{*}{$\frac{\text { DICY }}{1-5}$} \\
\hline Linearity & $(\mu \mathrm{g} / \mathrm{ml})$ & & \\
\hline & Regration equation & $Y_{\text {RANTD }}=0.034 \mathrm{x}-0.00001$ & $Y_{\text {DICY }}=0.090 x+0.020$ \\
\hline & $\mathrm{R}^{2}$ & 0.999 & 0.997 \\
\hline \multirow{4}{*}{$\begin{array}{l}\text { Precision } \\
(\% \mathrm{RSD})\end{array}$} & System & 0.24 & 0.22 \\
\hline & Method & 0.41 & 0.26 \\
\hline & Intraday & 0.06 & 0.32 \\
\hline & Interday & 0.56 & 0.446 \\
\hline LOD & $(\mu \mathrm{g} / \mathrm{ml})$ & 0.0097 & 0.205 \\
\hline LOQ & $(\mu \mathrm{g} / \mathrm{ml})$ & 0.029 & 0.622 \\
\hline \multirow{3}{*}{$\begin{array}{l}\text { Accuracy } \\
\%\end{array}$} & $80 \%$ & 100.25 & 98.75 \\
\hline & $100 \%$ & 98.86 & 100.50 \\
\hline & $120 \%$ & 99.05 & 100.83 \\
\hline
\end{tabular}

\subsection{Assay (Quantification of RANTD and DICY in tablet dosage form)}

The proposed method was applied for the determination of RANTD and DICY in their combined pharmaceutical formulation and the \% Recoveries confirm the suitability of the proposed method for routine determination of these components in combined formulation.

Table 11 : Results of Assay for RANTD \& DICY in marketed formulation

\begin{tabular}{||l|l|l|l|l|l|l|l|l||}
\hline $\begin{array}{l}\text { Formulation } \\
\text { (Tablet) }\end{array}$ & \multicolumn{2}{|l|}{$\begin{array}{l}\text { Amount of drug } \\
\text { taken(mg) }\end{array}$} & \multicolumn{2}{l|}{$\begin{array}{l}\text { Amount of drug } \\
\text { found(mg) }\end{array}$} & \multicolumn{2}{l|}{$\begin{array}{l}\text { \% Assay } \\
\text { Mean* } \pm \text { SD (n=3) }\end{array}$} & \multicolumn{2}{l||}{$\%$ RSD } \\
\hline \multirow{2}{*}{ RADIC } & RANTD & DICY & RANTD & DICY & RANTD & DICY & RANTD & DICY \\
\cline { 2 - 9 } & 15 & 2 & 15.05 & 1.99 & $\begin{array}{l}100.46 \pm 0 \\
.0029\end{array}$ & $\begin{array}{l}99.61 \pm 0 \\
.0020\end{array}$ & 0.298 & 0.297 \\
\hline $\begin{array}{l}\text { REDEN- } \\
\text { PLUS }\end{array}$ & 15 & 2 & 14.88 & 2.01 & $\begin{array}{l}99.41 \pm \\
0.0041\end{array}$ & $\begin{array}{l}100.4 \pm \\
0.0021\end{array}$ & 0.821 & 0.268 \\
\hline
\end{tabular}

* Average of three determinations. 


\section{CONCLUSION}

A simple, accurate and rapid Absorption correction UV Spectrophotometric method was developed and validated for the simultaneous estimation of Ranitidine Hydrochloride and Dicyclomine Hydrochloride in their combined marketed formulation. The advantage lies in simplicity of sample preparation and the low costs of reagents used. The proposed method assured satisfactory linearity, accuracy and precision. Analysis of tablet sample containing Ranitidine Hydrochloride and Dicyclomine Hydrochloride showed no interference from the common excipients and additives. The proposed method can be easily and conveniently used for routine quality control analysis

\section{IV.AKNOWLEDGEMENT}

The authors would like to thank, N. R. Vekaria Institute of Pharmacy, Junagadh and Dr. S. Sai Sivam Principal of N. R. Vekaria Institute of Pharmacy for providing necessary facilities to carry out the work.

\section{REFERENCES}

[1] Ahuja S. and Scypinski S. Handbook of Modern Pharmaceutical Analysis; Volume III - Separation Science and Technology; 1st Edn; Academic Press, New York, 2001, pp I - 22.

[2] Parimoo P. Pharmaceutical Analysis; 1st Edn, CBS Publishers and Distributors, New Delhi, India, 1999, pp I - 13, 145 - 177.

[3] Mendham J., Denny RC., Bannes JD., Thomas M. and Sivasankar B. Vogel's Text Book of Quantitative Analysis, 6th Edn, Doaling Kindersley (India) Pvt. Ltd., 2009, pp 1 - 13.

[4] Watson DG. Pharmaceutical Analysis; 2nd Edn; Elsevier Churchill, Livingstone, 2005, pp 87 - 88, $267-268$.
[5] Munson JW. Pharmaceutical Analysis Modern Methods - Part B; Indian Reprint, Marcel Dekker Inc., New York, 2001, pp 15 - 114.

[6] George L. and Schmuff N. HPLC Methods for Pharmaceutical Analysis; John - Wiley and Sons, New York, 1996, pp 682 - 698.

[7] Skoog DA., Holler FJ., and Crouch SR. Principle of Instrumental Analysis; 5th Edn; Thomson Brooks/Cole publication, Cengage learning India Pvt. ltd., New Delhi, 2001, pp 85-106.

[8] Schirmer RE., Morden Methods of Pharmaceutical Analysis; 2nd Edn; Volume II, CRC Press, Bosten, 2000, pp 239-438.

[9] Khopkar SM. Basic of Concept of Analytical Chemistry; 3rd Edn; New AGF International Pvt. Ltd. Publisher, New Delhi, 2008, pp 1-5

[10] Beckett AH. and Stenlake JB. Practical Pharmaceutical Chemistry; 4thEdn; Part-II, CBS Publishers, Delhi, 2001, pp 325-337, 85-106.

[11] Block JH. and Beale JM. Wilson \& Giswold's Textbook of Organic Medicinal \& Pharmaceutical Chemistry; 11th Edn; Lippincott Williams \& Wilkins, 2004, pp 948 - 956.

[12] Willard HH., Merritt LL., Dean JA., and Settle FA. Instrumental method of analysis; 7th Edn; CBS publishers and distributors, New Delhi, 1986, pp 614-629.

[13] Settle F. Handbook of Instrumental Techniques of Analytical Chemistry; 1st Edn, 2004, pp 19-21, 609-617.

[14] Kar A. Pharmaceutical Drug Analysis; 2nd Edn; New Age International (P) Limited Publishers, India, 2005, pp I - 2Christian GD. In: Analytical Chemistry; 4th Edn; John Wiley and Sons, United Kingdom, 1986, pp 1-6.

[15] Kennedy JH. Analytical Chemistry-Principals; 2nd Edn; Saunders College Publishing, New York, 1990, pp 1-8.

[16] The Merck Index, 14th edition, Merck Research Laboratories Division of Merck \& Co., Inc., USA, 2006, pp 1392, 1542 - 1543. 
Bhumi Kantariya et al Int J Sci Res Sci Technol. March-April-2019; 6 (2) : 851-863

[17] Patel R, "An Introduction to Analytical Method Development for Pharmaceutical Formulations", July 2008. Available from: http://www.pharmainfo.net/reviews/ introduction-analytical-method-developmentpharmaceutical-formulations

[18] Michael E., and Schartz IS. Analytical method Development and validation, CRC Publication, Bosten, pp 25-46.

[19] Saraf S, "Various UV spectrophotometric Simultaneous estimation methods.", April 2006, www.pharmainfo.net/reviews/various-uvspectrophotometric-simultaneous-estimationmethod

[20] Chatwal GR. and Anand SK, Instrumental Methods of Chemical Analysis, Reprint of 5th Edn; Himalaya Publishing House, Mumbai, 2007, pp $2.107-2.148$

[21] Sharma BK. Instrumental methods of chemical analysis; 19th Edn; Goel publishing House, Meerut, 2000, pp 1-4,133-161.

[22] Quality Assurance of Pharmaceuticals; A Compendium of Guidelines \& Related Materials, Volume - II; GMP \& Inspection, Updated Edn; World Health Organization, Geneva, AITBS Publishers \& Distributors, India, 2007, pp 16.

[23] International Conference on Harmonization, "Q2R1: Validation of Analytical Procedures: Text and Methodology." Federal Register 1997, 62(96), 27463-27467.

[24] "ICH/CPMP guidelines Q2A, Text on Validation of Analytical Procedures", 1994.

[25] "ICH/CPMP Guidelines Q2B, Validation of Analytical Procedures- Methodology", 1996.

[26] US FDA, "General principles of validation", Rockville, MD, Center for Drug Evaluation and Research (CDER), May 1987.

[27] US FDA, "Guidelines for submitting samples and analytical data for method validation", Rockville, MD, Center for Drugs and Biologics Department of Health and Human Services, Feb. 1987.

[28] ICH Harmonised Tripartite Guideline, Validation of Analytical Procedures: Text and Methodology
Q2(R1). Available from: http://www.ich.org/file admin/Public_Web_Site/ICH_Products/Guidelin es/Quality/Q2_R1/Step4/Q2_R1_Guideline.pdf

[29] FDA Guidance for Industry: Analytical Procedures and Methods Validation - Chemistry, Manufacturing, and Controls Documentation. Available from: http://www.fda.gov/downloads/Drugs/Guidance ComplianceRegulatoryInformation/Guidances/uc m 122858.pdf

[30] Green JM, "A practical guide to analytical method validation." Anal. Chem. News \& Features, 1996, 305A-309A.

[31] Ravichandran V, Shalini S, Sundram KM and Rajak H, "Validation of Analytical Methods Strategies \& Importance", Int. J. Pharma. Pharma. Sci.2010, 2(3), 18 - 22.

[32] Brunton L., Lazo J., and Parker K. Goodman \& Gilman's. The Pharmacological basis of therapeutics; 11th Edn; MacGraw's Hill, New York, 2006, pp 978-980.

[33] Sweetman SC, Martindale: The Complete Drug Reference, 36th edition, Pharmaceutical Press: London - Chicago, 2009, pp 1765, 1028 - 1029.

[34] Rang HP., Dale MM., Ritter JM., and Flower RJ. Pharmacology; 6th Edn; Elsevier Publication house, New Delhi, 2003, pp 385-390.

[35] Tripathi KD. Essentials of medical pharmacology; 5th Edn; Jaypee brothers Publication, New Delhi, 2004, pp 587-598.

[36] Image Collection: Medical Anatomy and Illustrations: Picture of Peptic Ulcer [updated 2012]. Available from:

[37] http://www.medicinenet.com/imagecollection/peptic_ulcer_picture/picture.htm

[38] Ranitidine [Internet] [updated 2012]. Available from:

http://www.en.wikipedia.org/wiki/ranitidine

[39] Drug Bank Open Data Drug \& Drug Target Database, Ranitidine [Internet] [updated 2010]. Available from:

http://www.drugbank.ca/drug/DB00863. 
[40] Dicyclomine [Internet] [updated 2012]. Available from:

http://www.en.wikipedia.org/wiki/dicyclomine

[41] Dicyclomine [Internet] [updated 2012]. Available from: http://www.medicinenet.com/dicyclomine /article.html

[42] Drug Bank Open Data Drug \& Drug Target Database, Dicyclomine [Internet] [updated 2011]. Available from: http://www.drugbank.ca/drug/DB00804

[43] Indian Pharmacopoeia. Volume II, The Indian Pharmacopoeia Commission, Govt. of India Ministry of Health and Family Welfare, Ghaziabad, 2010, pp 1206, 2045-2046.

[44] British Pharmacopoeia, Volume III, HMSO Publication, London, 2004, pp 2356-2357, 27092710.

[45] United State Pharmacopoeia. Volume III, 30th Edn, USP convention, Inc, Rockville, 2007, pp 1948,3160 .

[46] Kantariya B, "Development and Validation of a RP-HPLC Method for the Simultaneous Estimation of Ranitidine Hydrochloride and Dicyclomine Hydrochloride in Tablet Dosage Forms” Int. J. Phar. Res. Sclo.,2013, 2(2), 22777873.

[47] Mishra A and Rana A, "UV spectrophotometric determination of Ranitidine Hydrochloride in pure and pharmaceutical formulation." Int. J. Chem. Sci., 2009, 7(3), 2208-2210. .

[48] Salve P, Gharge D, Kirtawade R, Dhabale P and Burade K, "Simple validated spectroscopic method for estimation of Ranitidine from tablet formulation.” Int J Pharm. Tech. Res. 2010, 2(3), 2071-2074.

[49] Narayana B, Ashwini K, Shetty D and Kunnummel V, "Spectrophotometric determination of Ranitidine Hydrochloride based on the reaction with $\mathrm{p}^{-}$ Dimethylaminobenzaldehyde." Eurasian J. Anal. Chem. 2010, 5(1), 63-72.

[50] Charde MS, Walode SG, Tajne MR and Kasture $\mathrm{AV}$, "UV-spectrophotometric estimation of
Ranitidine and Domperidone in tablet formulations." Indian J. Pharm. Sci.2006, 68, 6589.

[51] Haque T, Talukder M and Laila S, "Simultaneous estimation of Naproxen and Ranitidine $\mathrm{HCl}$ by using UV spectrophotometer." Stamford J. Pharm. Sci. 2008, 1(1\&2), 18-24.

[52] Singhvi I and Pillai S, "Spectrophotometric simultaneous estimation of Ranitidine Hydrochloride and Ondansetron Hydrochloride from tablet formulation." Indian J. Pharm. sci. 2007, 69(4), 601-604.

[53] Walash M, Sharaf DM and Metwalli ME, "Spectrophotometric determination of Nizatidine and Ranitidine through charge transfer complex formation.” Arch. Pharm. Res. 2004, 27,720.

\section{Cite this article as :}

Bhumi Kantariya, Dr Greeva Bhatt, Dr. Mehul Mehta, Urmi Kanatria, Ravi Dalsaniya, " Development and Validation of Absorption Correction UVSpectrophotometry Method for Simultaneous Estimation of Ranitidine HCL and Dicyclomine Hydrochloride in Their Marketed Formulation", International Journal of Scientific Research in Science and Technology(IJSRST), Print ISSN : 2395-6011, Online ISSN : 2395-602X,Volume 6, Issue 2, pp.851863, March-April-2019. Available at doi : https://doi.org/10.32628/IJSRST218140 Journal URL : https://ijsrst.com/IJSRST218140 